\title{
TADEUSZ GERSTENKORN
}

University of Łódź

Faculty of Mathematics and Informatics

tadger@math.uni.lodz.pl

\section{PROFESSOR TADEUSZ KOTARBIŃSKI AND PHILOSOPHY AT THE TIME OF HIS TERM OFFICE AS RECTOR AT THE UNIVERSITY OF LÓDŹ IN A FORMER STUDENT'S REMINISCENCES}

\begin{abstract}
Youth is the best time in every human's life. At the same time, it is a period of certain inferiority and a search for personal patterns as well as authorities of moral conduct and social behaviour; it is a period of searching for wise life-guides who can stir our dormant talents and direct them to the right scientific interests.
\end{abstract}

The period of World War II and the time of the German or Soviet occupation prevented young Poles from regular personal and educational development. At that time, they either fought in the guerrillas or were forced to work for the Nazis.

In June 1945, I received the so-called small secondary school diploma or certificate of completion of the $4^{\text {th }}$ form (in accordance with the prewar rules) in Nicolaus Copernicus high school in Łódź (there I had the good fortune to start my secondary school education in 1939). I passed the regular secondary schoolleaving exams at the science-oriented adult secondary school that was located in the same building. Adult secondary school was an absolute necessity for me then. Both in junior high school and in secondary school I had excellent teachers, partly later university lecturers, such as Lucjan Cieślik - physicist (Łódź University of Technology), and Władyslaw Terlikowski - mathematician (Łódź University of Technology). When I recollect that school period, even today I am amazed at their ability to convey in a very short time the immensity of knowledge to educationally late young people. It is simply hard to believe, but we were really good and comprehensively prepared for higher education. Admission to some colleges and universities depended on successfully passed entrance examinations, and often - on political support. I got to Łódź University of Technology with no problem at all, but I decided to study the humanities at the University of Łódź for two vital reasons. Firstly, my mother was seriously 
ailing, so I had to help her with her daily problems (studying the humanities would make it easier for me) and secondly, general knowledge and especially the study of the structure of thinking seemed more attractive to me, and it was philosophy that - to a large extent - could meet my expectations.

In the academic year of 1946/47, just when I started my university education, Professor Tadeusz Kotarbiński, a known and recognized philosopher, was the first rector of the University of Lodz. In that year I did not have an opportunity to come into contact with him, but I clearly felt the effects of his managing of the new (founded after the war) University. Professor Kotarbiński was a supporter of a liberal university, that is, one where people with different views - either idealistic or quite opposite ones - were free to conduct scientific activities. It was important that the suggested theories were clearly presented and properly substantiated. During the first year of my studies, thanks to such a policy of managing the University, I had the good fortune to listen to lectures by such celebrities as Janina Kamińska (previously named Dina Szteinbarg, and a year later - Kotarbińska as Tadeusz Kotarbiński's wife), who would deliver lectures in logic in an exceptionally interesting way. In the academic year $1947 / 48$, I was able to participate in the introductory seminar in logic held by Professor Janina Kotarbińska and listen to her talk on Methodology of Humanities.

In a lecture titled The Architectonics of Being, Professor Benedict Bornstein presented his original ontological idea. He also had a lecture - with reference to Immanuel Kant - on A priori Synthetic Judgements. In the academic year 1947/48, Professor Bornstein gave a lecture titled Introduction to Philosophy and a seminar Prolegomena to Any Future Metaphysics (Kant). I clearly remember his tall, noble figure. Unfortunately, he died soon afterwards, in 1948.

It was impossible to forget exciting lectures in psychology delivered by Professor Albert Dryjski. The Professor always quoted interesting psychological problems and then strived to solve them employing different kinds of methods. In the academic year 1947/48, during his four-hour lectures, Professor Dryjski discussed and visually presented endless topics. His textbook was read like a novel. In addition to the lecture we had the opportunity to participate in twohour psychology classes or in a seminar.

Professor Wiktor Wąsik also conducted his lectures in a very vivid way. I admired his erudition. He often changed the subject of his discourses. He discussed medieval and positivist philosophy (1947/48), Old Polish views on education as well as idealism of the 19th century (1948/49), and philosophy of the Enlightenment (1949/50). Professor Wąsik also held a seminar in the history of philosophy and he was the examiner during my exam in the history of philosophy. Dr. Stanisław Czajkowski (1904-1961) was an assistant professor in the Department of the History of Philosophy run by Professor Wąsik. 
Dr. Czajkowski - educated at French universities - was an expert on Descartes's philosophy. He had a very cheerful disposition which could be observed in his lectures. He always delivered them with great passion, commitment and a nice smile on his face.

Professor Mieczysław Wallis had his lectures on the $1^{\text {st }}$ floor of the building in Lindley'a Street. I remember that figure very well. He was a "walking," and, one can say, a "talking aesthete". He had a two-hour lecture on The science of art and a one-hour lecture on The history of aesthetics. I have to point out that all the lecturers of that time, and Professor Mieczysław Wallis in particular, knew how to take good care of the beauty of Polish language. It was important to the post-war students who were for more than 5 years of occupation deprived of a native speech pattern.

The lectures delivered by Professor Sergiusz Hessen were also of a great interest to students, as he presented pedagogical theories in a very stylish way. I remember his three-hour lecture titled The History of Ancient Philosophy with Emphasis on Pedagogical Doctrines. Professor Hessen was a versatile scholar, a specialist in the theory of education, but also in the philosophy of culture and law. Professor Hessen's activity at the University of Łódź was a continuation of the classes at the branch of the Free Polish University in Łódź. The same can be said about Professor Wąsik and Professor Bornstein as well.

The University authorities suggested that philosophy students, and especially logic and methodology of science students, should hear a lecture in science. I chose mathematics and Profesor Stanisław Mazur's lecture on Differential and Integral Calculus and Higher Algebra. Professor Mazur did not work at the University of Lodz for a long time. He was a great mathematician but of the Lvov School, yet it was politics that attracted him more. He came to participate in high-level authorities of the state.

Ethical thought was represented at that time by Professor Maria Ossowska. In the academic year 1948/49, she had a lecture titled Personal Patterns in European Antiquity. Klemens Szaniawski, later professor of the University of Warsaw and its rector, was one of her collaborators.

I got to know Professor Tadeusz Kotarbiński's teaching and scientific activity only in the later period of my studies. In the academic year 1949/50, the Professor had a monographic lecture entitled Science Classification and a philosophical seminar. I attended that seminar also in the following year, before my graduation. I was fascinated by the way he conducted the meetings. Among other things, we discussed texts from the textbook by Tadeusz Czeżowski, professor of the University of Torun, who had been a philosopher at the University of Vilnius (Czeżowski and Kotarbiński met by chance in 1912 at a philosophical introductory seminar in Lvov. They sat next to each other and 
so it started.). After reading a passage we made a thorough linguistic, semantic and factual analysis of it. It was a great school of searching the meaning hidden in words, a school of thinking analysis and of learning how to define concepts properly and express yourself precisely. A nice thing about the seminar was also its enchanting, almost family atmosphere. The Professor treated his students very seriously. He always encouraged them to participate in discussions.

The Professor could appreciate his students and many of them won a large dose of his trust. Let me give an example. Tadeusz and Janina Kotarbinski (the Professor got married to Janina Kamińska) lived near the rector's office, in a building at 3 Uniwersytecka Street, on the second floor. Their flat was on the south side. The offices on the west side were for a seminar room and a library. There was also the Professor and his wife's small study. During one summer vacation it came about that there was no one to give the seminar, though there were close associates such as Marian Przełęcki and Leszek Kołakowski who were outstanding scholars a little bit later. I offered to perform the duty and my offer was accepted. I got the key to the seminar room, access to the library and to the professor's personal desk.

The way of managing the University did not match the then Communist authorities' politics, which was ideologically based on Marxism-Leninism. It inevitably lead to an ideological attack on the Professor - performed largely by a then popular sociologist, Professor Józef Chałasiński - in extensive articles published in the journal "Myśl Filozoficzna". Up until 1949 (when Kotarbiński's term of office as rector was about to end), ideologically awkward professors were dismissed. Professor Dryjski was offered a Russian language course. He died shortly after that (1956), probably from worry. Professor Wąsik retired on $1^{\text {st }}$ November 1950. Born in 1883 he found his place first at the Catholic University of Lublin (1952/53-1955/56), and then, until his death in 1963, he was head of the Department of the History of Philosophy at the Theological Academy in Warsaw, which was founded after the Theological Faculty at the University of Warsaw had been liquidated. Professor Bornstein died in 1948.

I wrote my master's thesis (The Principle of the Economy of Thinking According to Ernst Mach) under Professor Janina Kotarbińska's supervision. The subject was suggested by Professor Kotarbińska. The principle of the economy of thinking belonged to the philosophical movement of the end of $19^{\text {th }}$ and the beginning of $20^{\text {th }}$ centuries. It was formulated by an Austrian philosopher, Ernst Mach, and, independently of him, by a German-Swiss philosopher, Richard Avenarius, and was known as empirical criticism or empirio-criticism. Ernst Mach (1838-1916) was an Austrian physicist. From 1864 he was professor of physics in Graz, and from 1867 in Prague. He was also keenly interested in philosophy, and from 1895 to 1901 he worked as professor of philosophy at the University of Vienna. Empirical criticism was also known as machism. 
Interestingly enough, he, as a physicist, was involved in the study of phenomena accompanying the supersonic movement of bodies. Richard Avenarius (184397) was a German philosopher working in Switzerland, and from 1876 onwards he was professor at the University of Zurich. He formulated empirical criticism independently of Ernst Mach. He called for the acknowledgement of philosophy as a science. He also advanced the thesis that the existence of the external world depends on the learning subject (mind). Empirio-criticism reduced the whole of reality to human sensations (Empfindungen). With the help of the so-called "pure experience theory", empirio-criticism attempted to remove the opposition between idealism and materialism, which led to an attempt at combining empirio-criticism with Marksism. Avenarius's views were contained in his Der menschliche Weltbegriff (1891; Eng.: The Human Concept of the World; Polish: Ludzkie pojęcie świata, 1969) and were fiercely criticized by Lenin in his philosophical work Materialism and Empirio-criticism (1909).

Ernst Mach's philosophical works (originally published in German) are as follows: Die Analyse der Empfindungen (1886; Eng. The Analysis of Sensations) and Erkenntnis und Irrtum (1905; Eng. Knowledge and Error). Polish translations of the works do not exist. Lenin's views on empirio-criticism have been available in Polish language for a long time.

The time in which I wrote my master's thesis was a period of sharp ideological struggle and the subject of the thesis showed that status quo appropriately. The work was reviewed by Professor Kotarbiński. I had my final exam in the philosophical seminar room at 3 Uniwersytecka Street at the end of academic year 1950/1951. During the written exam, it was necessary to comment extensively on one of the three given topics.

Obtaining a diploma in philosophy that was written under Professor Kotarbińska's supervision and reviewed by Professor Kotarbiński was a matter of prestige. Still in the same academic year, I started lecturing in logic at the Pedagogical Academy in Łódź, located then at 21 Aleja Kościuszki. Dr. Hanna Szmuszkowicz, Professor Mazur's wife, was the rector of the Academy. Unfortunately, I had lectures for only one year. In 1952, the then authorities introduced regulations (following the Soviet example) that logic and psychology, as an influence of Western imperialism, could not be taught in Poland. That state of affairs lasted for several years. Changes came after 1956.

After many years, looking from the perspective of the time, you can ask yourself: was it worth studying philosophy?

For centuries, part of human society - aware of the need of knowledge - has been looking for answers to the most asked questions about man and his being in the world, about morality and behaviour in the community. To reflect on life and its problems is a natural need for a thinking creature. We often call such 
a reflection philosophy, and if it is supported by valid, logical thinking, it is usually reflected in the scientific dissertations that are propagated in discussions or publications. Sometimes it has a considerable impact on the views, actions, deeds and lives of many communities. The history of mankind confirms that Philosophy is the love of wisdom. It would be great if everyone could say so.

On the prewar syllabus for the second form of high school there was a subject named Introduction to philosophy. There was an excellent textbook that was of a great help to teachers. Along with the new political system, the obligation to think logically and to drill the principles of logical thinking into the young generation vanished. The effects of the lack of proper thinking and inability to draw conclusions are very unpleasant for society. One can see and feel that. It has been suggested recently that junior academics or even senior researchers of the philosophy departments give lectures on philosophical subjects in secondary schools.

Maybe it would bring a chance to change something? 